\title{
Hybrid
}

Revue des arts et médiations humaines

\section{Inhabiting fantasy ecologies: literature meets video games}

\section{Pierre-Louis Patoine}

Translator. Saskia Brown

\section{(2) OpenEdition Journals}

\section{Electronic version}

URL: https://journals.openedition.org/hybrid/398

DOI: $10.4000 /$ hybrid.398

ISSN: 2276-3538

This article is a translation of:

Habiter les écologies fantasy : la littérature face au dispositif vidéoludique - URL : https:// journals.openedition.org/hybrid/309 [fr]

\section{Publisher}

Presses universitaires de Vincennes

\section{Electronic reference}

Pierre-Louis Patoine, "Inhabiting fantasy ecologies: literature meets video games", Hybrid [Online], 5 | 2018, Online since 18 December 2018, connection on 13 April 2022. URL: http:// journals.openedition.org/hybrid/398; DOl: https://doi.org/10.4000/hybrid.398

This text was automatically generated on 13 April 2022.

Revue Hybrid 


\title{
Inhabiting fantasy ecologies: literature meets video games
}

\author{
Pierre-Louis Patoine
}

Translation : Saskia Brown

1 Nineteenth-century innovations in optics, chemistry and mechanics were the seedbed for the invention of photography. This technique proved to harbour within it another art form, which had a natural affinity with narrative, namely film. Film grew out of the photographic medium, and gradually extricated itself from the dominant theatrical and literary narrative codes of the time. It established its own aesthetic and its own conventions which, in turn, had a major impact on twentieth-century literature and theatre.

2 The digital media have developed in a similar way. They emerged in the last decades of the twentieth century as the product of different branches of mathematics, logic, and physics, and as the culmination of a history which includes Babylonian, Euclidian, Persian and Arabic algorithms, Jacquard looms with their punched cards (1801), Charles Babbage's analytical engine, imagined in 1834, and Turing's machine a century later, Belle Epoque unit record equipment and transistors with integrated circuits. Just as photography gave birth to film (and not only to the roman photo and to filmed theatre), computing gave birth to video games in the 1960 s and 1970s (and not only to eliterature and interactive film). Video games were quick to focus on narrative, inventing new ways of telling stories, and new narrative and stylistic strategies. These crystallised in the 1980s and 1990s at the same time as a real growth spurt in video gaming, which continued into the first decades of the twenty-first century. Today, it seems essential to understand the impact of this art form, which is an offshoot of computing, on our culture, and particularly on the way we practise literature. What becomes of literature in a technological environment which is increasingly permeated by the computer?

3 In this article, we shall formulate a partial and provisional answer to this question, by examining a particular field of influence defined by a remark by N. Katherine Hayles on electronic and print publication narrative forms, in her Electronic Literature: "They 
compete and cooperate not only in terms of design, style and thematic content, but also in terms of reader preferences and styles of engagement." It is these preferences and modes of engagement of players and readers that will concern us here. So we shall not attempt to assess how computing and literature swop themes and images, but rather to understand the particular uses of narrative and fiction that are generated where electronics meets literature.

In this inquiry, we shall focus on the practices and modes of engagement of the gamer/ reader in the genre of Fantasy, which literature and video games have in common. Fantasy's aesthetic, narrative, and thematic specificity is the creation and exploration of secondary, imaginary or virtual, universes. These universes encourage immersion in the text, originally in literature, and centrally in video games. Today, readers expect immersive experiences, and retrospectively valorise the founding texts of geek and video gaming culture in this light.

Modern Fantasy developed from the 1930s to the 1970s thanks to authors such as Robert E. Howard, Fritz Leiber, J. R. R. Tolkien, Michael Moorcock and Ursula Le Guin, who laid the bases for its future influence. They shaped the aesthetic and imaginative framework in which Gary Gygax and Dave Arneson developed the role-playing game Dungeons \& Dragons, in 1974. At the time, the first major generation of programmers were teenagers or young adults. They met up to play Dungeons \& Dragons, devoured the books of the authors we just mentioned, and computing proved to be a powerful tool for prolonging their "fantasy experience." ${ }^{2}$ This period saw the beginnings of interactive fiction, with "text adventures" such as Adventure (1975) and Zork (1977), which paved the way for what would become role-playing video games. In the 1980s, Fantasy became an intermedial field, expanded by a community of creative and adventurous enthusiasts such as Steve Jackson and Ian Livingston, who combined roleplaying, programming, and children's literature to create the first ever "book in which YOU become the hero!" (Warlock of Firetop Mountain (1982)). Two years later, the publishing company TSR Inc. launched the Dragonlance series of fantasy novels (cowritten by Margaret Weis and Tracy Hickman), to accompany the Dungeons \& Dragons gaming modules. In 1988, the role-playing video game Pool of Radiance, and the shared universe of Forgotten Realms inspired a novel of the same name, published by TSR in 1989. These fantasy works, both literature and video games, have one feature in common: they are built around worlds that can be explored, and often shared with others, and they encourage a form of spatial and geographical immersion in the surroundings.

Exploration and spatial immersion were of course not invented by modern Fantasy. There is a long tradition, in the West, of "spatial narratives," going back as far as the Epic of Gilgamesh, the Iliad and the Odyssey, Beowolf, various forms of travel narrative, and pastorals, Utopias, and the adventure novel. But in the 20th and 21st centuries, there is no doubt that it is Fantasy (and science fiction) which have most consistently featured the experience of immersion, exploration and inhabiting new worlds, and these are the relations we shall attempt to describe here.

\section{Role-playing video games}

7 Although video games can be considered to be "one of the most productive areas for narrative of all the digital media" (Marie-Laure Ryan), ${ }^{3}$ not all its branches are equally 
interested in narration. For those which are, it is role-playing video games, the direct heirs of the tabletop role-playing game (or RPG) Dungeons \& Dragons which have proved to be particularly inventive in the complexity of their plots, which are often structured around a quest which mobilises the hero, or group of heroes. As James Newman states, "the story, and the richness and the complexity of the dialogues and characters in roleplaying video games, are vital elements of this most literary of genres." It is a genre which "creates the link between video games and other literary forms." ${ }^{4}$

8 We shall therefore focus primarily on RPG, and on how this genre fulfils the archaic desire for a moment's escape from the contingencies of daily life, in order to inhabit a "better world", and be immersed in a magical environment. ${ }^{5}$ As King and Borland say, it comes as no surprise that each of the three components that enable this escapismfantasy literature, role-playing and computing-has a magical dimension, giving access to a form of transcendance of daily life and the human condition through the imagination or through technology. ${ }^{6}$

\section{Technology, the source of a world}

9 So within the sphere of Fantasy, computer technology (programming and interactivity), the techniques of games (rules and systems), as well as literary ingredients (conventions of genre, narrative and figurative forms) came together in the 1970s to simulate explorable secondary worlds able to expand our Umwelt wherever we are, and so to contribute to the biological and aesthetic development of the human being and his sense of habitat. As Montani states:

Human life forms are technological from the start, in that they are constituted by externalising themselves in non-organic extensions, which influence to a greater or lesser extent-but at all events decisively-the human being's sensibility, and, coessentially, the world of things which this sensibility encounters and works on. ${ }^{7}$

10 Fantasy worlds would be one example of non-organic extensions of our environment, which alter our sensibility in providing refuge and shelter. Just as a house is the external technological form taken by our internal temperature regulation system (among others), these fictional worlds make collectively shared iconic and symbolic artefacts into repositories of the biological functions of the "animal body," particularly its homeostatic functions of regulation of stress and tension. Fictional habitats thus extend the process of hominisation described by Leroi-Gourhan in Gesture and Speech. ${ }^{8}$

11 The spatial dimension of literary narratives breathes life into fictional habitats. Arguing that narrative practices exercise the cerebral and cognitive structures developed during the human species's evolution, Christopher Collins maintains that "hearing a story is therefore analogous to moving through objects in a spatial field, but now, instead of a landscape, we are moving through a soundscape, and, instead of an

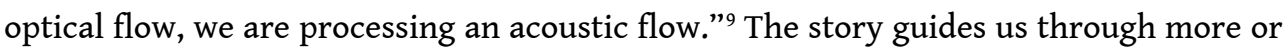
less inviting environments, thanks to the linguistic categories that translate specific aspects of this spatial navigation. Names-which, as we shall see, are central to creating secondary worlds and the visual environment-are therefore, for Collins, the equivalents of what the eye sees, of the figures we pick out on the edges in the background, when we are exploring our immediate surroundings. ${ }^{10}$ The experience we have of our environment when listening to a story (and all the more so in a video game story) reenacts the oscillation between the safety of a refuge and the stress of 
exploration. ${ }^{11}$ We shall return to this point, but we can already note that this oscillation may, in a complex way, correspond to the association of narrative and description. The geographer Yi-Fu Tuan maintains that in primitive societies story-telling was linked to the practice of hunting and exploration (which follow the classical narrative schema of the epic quest), whereas gathering, which took place near to places of shelter, can be linked to detailed description. ${ }^{12}$

In the genre of Fantasy, the description-refuge often seems to bring a moment of calm, of freedom from the demands of action, from the syntactical sequence of causes and effects, that is, from the progress and resolution of the plot. Picturesque landscapes and spectacular settings unfold, which the reader is pleased to inhabit for a time. Advances in computer science made it possible for these magical worlds, which until then had been confined to the literary imagination, to become suddenly visible, explorable and inhabitable. We were suddenly able to interact with these worlds without the constraints (or the advantages) of tabletop role-playing games. The developing field of computing immediately harnessed its futuristic potential to archaic fantasies of transcendance, and mythical, epic and heroic reveries. The first programmers, akin to electronic shamans, gave us access to fairytale worlds full of sensations, inviting us to cross the hypnotic surface of the screen and explore these worlds rooted in a literary tradition, whose most famous twentieth-century contributor was doubtless Tolkien.

\section{Tolkien, Fantasy and secondary worlds}

13 Within the set of influences whose key features we are attempting to define here, Tolkien is not as central as his broad popular appeal might suggest. He is easily appropriated by an academic discourse because he was himself a professor of old English at Oxford, he wrote about his writing, and his work fits well with literary analysis as we practice it. This is quite different from the pulp writing of Robert $\mathrm{E}$. Howard, the inventor of Conan, who destabilises our approach and our critical tools. As a young Texan writing for a living, Howard is a perfect embodiment of that "other branch" of Fantasy, dynamic and irreverent, the branch behind Dungeons \& Dragons, and, later, behind video games. Howard was in fact the first author of modern fantasy to publish a "history" of his fictional universe, "The Hyborian Age." ${ }^{13}$ Despite the importance of this gesture, the world of Hyperborea is subordinated to its hero Conan: it is above all a stage for his adventures.

With Tolkien, by contrast, secondary worlds take precedence, and his works are basically a way of inhabiting them and spending time there. Middle-Earth and the world of Ea first figured in a children's novel (The Hobbit, 1937), then in a "sequel for adults" (The Lord of the Rings, 1954-1955), but they were actually created during the First World War, as Tolkien took refuge in his imagination from war in the trenches. There, he began taking notes, and wrote the first sketches of what would become the 12 volumes of his History of Middle-Earth and The Silmarillion. The latter tells the story of Ea, from its creation to the beginning of its Third Age (the period in which the The Hobbit and The Lord of the Rings are set). The tale told by The Silmarillion emerges in fragments as a patchwork of short, heroic stories and legends, which have little psychology but a great deal of genealogy and a great deal of geography, covering many 
territories and settings. Following The Silmarillion requires the reader to refer frequently to the map at the beginning of the book.

Tolkien's œuvre is, consequently, orientated ontologically, and from the start, towards objects, territories and surroundings. Considerations of genre are decisive here, as Tolkien suggests in his explanation of why theatre is not a suitable vehicle for fantasy: "You are, for instance, likely to prefer characters, even the basest and dullest, to things. Very little about trees as trees can be got into a play." ${ }^{14}$ Although this position is debatable, especially in the context of contemporary theatre, it show that Tolkien's novels sought to make space for the non-human, the non-psychological, and for the environment. We shall see that role-playing video games share this characteristic because they privilege the representation of the environment. So for Tolkien, fantasy narratives are characterised by an ontology, an environment, and immersion.

Fairy-stories are not in normal English usage stories about fairies or elves, but stories about Fairy, that is Faërie, the realm or state in which fairies have their being. Faërie contains many things besides elves and fays, and besides dwarfs, witches, trolls, giants, or dragons: it holds the seas, the sun, the moon, the sky; and the earth, and all things that are in it: tree and bird, water and stone, wine and bread, and ourselves, mortal men, when we are enchanted. ${ }^{15}$

Fantasy is clearly defined here in terms of its ecological density, its ability to create complete, inhabitable secondary worlds. Fairy-stories are not about particular creatures, but about their world, their plane of existence defined in terms of ecological elements (the seas, the sun, the moon, the sky; the earth, trees and birds), and of basic artefacts of human culture: bread and wine. For humans are also invited to travel through this world, on one important condition: that they be in a state of enchantment. Is this enchantment not the equivalent of immersion in one's surroundings, which is a hallmark of fantasy literature and video games?

\section{The spatial dimension of video games}

17 When computer technologies gave rise to video games, the link fantasy literature had made between secondary worlds and immersion or enchantment could be consolidated. In the ludologist Espen Aarseth's view, video games, as immersive and hypnotic media, "are essentially concerned with representing and negotiating space,"16 and Henry Jenkins maintains that "game designers do not just tell stories; they conceive worlds and sculpt space." ${ }^{17}$ However, it would be a mistake to reduce video games to their spatial aspect, and make this into a categorical imperative of the medium; games such as Football Manager (2004-2018) (sports team management), or Tokimeki Memorial (1994-2006) (a dating simulation series) prove this well enough. ${ }^{18}$ Yet Aarseth's and Jenkins's claims are particularly relevant for role-playing video games with a fantasty orientation. As Geoff King and Tanya Krzywinska state, "the spectacle offered by the environment [...] is particularly important in games which take place in spaces of high fantasy, which often create extended worlds composed of landscapes in different styles." 19

The more or less guided exploration of these landscapes organises the unfolding of the narrative of most RPGs and interactive fictions. Exploration was central to interactive fiction from the very start, with Adventure, which was created in 1975 by the programmer Will Crowther. Crowther was a Dungeons et Dragons player, but perhaps 
more importantly he was a caving enthusiast, who wanted to recreate the pleasures of exploration for his two daughters. Even if the first version of the game, called Colossal Cave, was purely textual, with no graphic interface, it was nonetheless spatial and exploratory, and inspired by specific, often spectacular, places, in the Mammoth Caves Park, Kentucky. ${ }^{20}$ But Crowther went further than simulating caves to be explored, in order to hold the attention of his daughters. He inserted elements that would mobilise and direct the exploration of this virtual space, namely five treasure-troves to be discovered, a snake which blocks the player's progress, the famous labyrinth made of "twisty little passages, all alike," and so on. These objectives and obstacles, which construct the narrative, orientated, and teleological aspect of the game, seem relatively independent of the pleasure of exploration, as Nick Montfort stresses: "There is also the feeling of exploring a world or a new space, independently of the events taking place in it, and which are recounted. The pleasure of this exploration is not linked to puzzles, and solving them." ${ }^{21}$ So there is a productive tension between the progress of the narrative and the attainment of the goals fixed by the game, on the one hand, and the spectacle of the environment, which begins to take on a life of its own, and to become a pleasure in itself. King and Krzywinska agree with this diagnosis, explaining that "many players of EverQuest and similar games spend a lot of time travelling to see the different spaces of the game-world, behaving like tourists within virtual landscapes," ${ }^{22}$ adding that "the exploration in itself can be a substantial source of this type of game's attractiveness." ${ }^{\prime 23}$ And Gordon Calleja, at the beginning of his book InGame, concerned with clarifying the concepts of immersion, presence and incorporation, narrates how when he was a young boy in Malta, "forests and mountain ranges [were] the stuff of fantasy itself, and having the chance to inhabit those landscapes [...] was an alluring part of digital games." ${ }^{24}$ The cult Japanese RPG Earthbound (1995) even alludes amusingly to this type of pleasure by adding a parody of a tourist guidebook, which describes the different places (spruce suburbs, a desert, a city, seaside resorts, a Nordic forest, and so forth). It even adds a photographer, who falls out of the sky all of a sudden, to immortalise the hero's presence on the most picturesque sites.

So, beyond the competitive pleasure of winning, or the directional, teleological desire to finish the game, a pleasure of exploration for itself would seem to be present, an aesthetic and sensual pleasure, produced by inhabiting and wandering through virtual environments. Is this sort of pleasure not also found in literature? That is, a pleasure not linked to plot development and progress, nor to solving a mystery, but rather to inhabiting an imaginary world. Is this not the immersive and sensual pleasure around which an "environmental" genre such as Fantasy is built?

\section{Inhabiting the text, inhabiting the game}

20 Alice Munro, the winner of the Nobel Prize for Literature 2013, describes how she reads, in an essay in which she summarises her vision of the short story:

So obviously I don't take up a story and follow it as if it were a road, taking me somewhere, with views and neat diversions along the way. I go into it, and move back and forth and settle here and there, and stay in it for a while. It's more like a house. ${ }^{25}$

21 Although this description is not applicable to all reading (but it seems particularly apt for re-reading, which is crucial to any notion of inhabiting the text), it says something 
about the desirability of this type of aesthetic relation. It involves a pleasure of reading which is detached from the directionality and unfolding of the narrative, and the goal to be reached at the end, privileging instead a form of inhabiting. One could say that Munroe rejects seriality and the syntagmatic, choosing instead the paradigmatic dimension, freed from the constraints of linear time.

The art book New Eden - A Book Celebrating Great Game Environment Design, developed in 2014 by three students from the University of Berlin (Christian Ernst, Alexander Venus and Robin Soyk), obeys a similar logic. It presents images from a variety of game environments and virtual spaces, abstracting them from their original context, where the player is often too absorbed in his or her "missions" to stop and contemplate the environment. The curator Jean-Jacques Launier started from a similar premise in his exhibition, "L'art dans le jeu vidéo" ["Art in the vido game"] (Art Ludique-Le Musée, Paris, 25 September 2015 to 6 March 2016); and several game art shows take the same approach. Over the last few decades, this branch of contemporary art has given us some fascinating examples of the charm of game environments when freed from the game's constraints, and the actions it requires. One of the first projects by Miltos Manetas, the pioneer of game art, was a machinima-type art video, that is, a video which uses only video game material. It was first shown in 1997, at the Institute of Contemporary Art in London, and was conceived with Andy Warhol's film Sleep (1964) in mind. This video game ready-made shows the famous Mario (from the game Super Mario 64, 1996) motionless in a verdant landscape with three butterflies fluttering slowly around him. He yawns, stretches, then sits down on the grass. He begins to nod off, stretches out on his side, and falls into a peaceful sleep. In the original game, this routine occurred whenever the player stopped moving Mario, but here it is extracted from its original context, so that we can concentrate on the quietly bucolic aspect of the game, and the player's desire to enter this Edenic environment and unwind there. Étienne Armand Amato provides a convincing explanation of how the difference between a stressful everyday world and the charmed and reassuring worlds of video games creates a "desire for immersion." ${ }^{26}$ The virtual environment really can be inhabited, representing a haven of peace, a place of refuge and protection, and a place to spend time in, by suspending action and objectives. This generates more intense attention to the environment, its textures, colours and sounds. One could argue that Miltos Manetas is using video games against their designed function, but is this really the case? Could it be that he is actually exploiting a potential that is inherent in the medium?

Cory Arcangel's Super Mario Clouds (2002), a work between retrogaming and art hacking, was made by changing the code of an original Mario Brothers cartridge (Super Mario Bros. [1985]) to substract all the elements of the game, except for the first-level white clouds floating in a blue sky. In a gallery setting, it is generally projected onto several walls, so that the spectators are surrounded by Shigeru Miyamoto and Takashi Tezuka's creative universe, reduced to its simplest element (the sky). The bucolic and contemplative feel of the work highlight the captivating nature of immersion in this secondary (meteorological) world. This relation to the game is quite the opposite of the speedrun, in which the player tries to finish the game as quickly as possible. With speedrunning, the feeling of these white clouds, and their sensual weight, is greatly diminished, and even entirely lost.

Similarly, the very popular RPG Skyrim, published in 2011, although basically a warfare game, was particularly appreciated for its long sequences of wandering through and 
exploring peaceful environments which change with the seasons and as one day follows the next. Many web videos invite this type of interaction, ${ }^{27}$ between exploration and inhabiting, aiming at a purely sensual, aesthetic pleasure of immersion. Players take pleasure in this aestheticised relation to a world which, in its geographical and climatic characteristics, has deep historical roots, as we have seen with Tolkien. ${ }^{28}$

\section{Narration and description}

Despite the fact that RPGs can be categorised as "games of progression"-which means, in the typology proposed by Jesper Juul, that they are structured as more or less linear sequences through which the player must progress, contrary to "games of emergence" such as card games, which can generate an infinite number of rounds on the basis of a few rules ${ }^{29}$-they can be really pleasurable for the player who wishes to explore the game environment in a leisurely way. Similarly, although fantasy literature tends to espouse the epic genre of the quest, it can also focus on inhabiting secondary worlds, as we have seen with Tolkien. In such cases, a time-related aesthetic cohabits with the fantasy text and game, which privilege a spatial dimension. Sensory immersion in spectacular environments becomes as important as the cognitive and emotional involvement in the plot's causal chains. The potential tension between the two can be conceptualised through the classical narratological opposition between description and narration.

In role-playing video games, playing to win pushes the narrative forwards, whereas exploring different environments simply for the pleasure of discovering and savouring them suspends narrative progress. In this sense, a "competitive" game is linked to resolution, that is, to a teleological narrative syntax, whereas exploring environments is closer to description, and a stroll through symbolic paradigms. The reader's or player's involvement oscillates between these two poles, but the dominant behavioural script and the standard tendency in reading and gaming remain getting to the end of the story, finishing the book or the game. However, readers and players can subvert this scripted behaviour by freely "wasting their time," inhabiting fictional spaces (particularly by rereading or replay), and immersing themselves as tourists in the spectacle of the game environments. Description becomes de-scription, the temporary destruction of the teleological drive of the narrative, and an escape from the orderly sequence of time by lingering in a des-scripted environment, which has shed the rules which normally govern our relation to it. Fantasy, when enhanced by computer technology in video games, can make this type of involvement particularly attractive.

These two modes of involvement are of course complementary, and the reader constantly passes from one to the other, from narrative progression to descriptive immersion. To expand on the latter, we should note, following Philippe Hamon, the central role of the noun or substantive in description. It is a core function which can be fleshed out, extended, and multiplied by a series of predicates..$^{30}$ Nouns have an autonomy which neither adjectives, adverbs nor even verbs have (since they are dependent on their subject and object). Indeed, although the noun's capacity to designate and evoke is usually curtailed by the particular sentence in which it is placed, it always threatens to break loose and build its own temple. Noun-worship is not unknown, as with Gertrude Stein ("A rose is a rose is a rose," Geography and Plays, 1922), or Francis Ponge (Le Parti pris des choses, 1942). Nouns are sovereign, since they bear the 
shadow of the world's presence, and the flavour of the absent object. Description is the reproduction on a larger scale of this logic of the sovereign name, which procures, as in the game art projects mentioned above, a "useless" pleasure at the spectacle presented by the virtual environment, a sensual and immersive experience divorced from the sequential steps of the action.

\section{From the sovereign noun to the spectacle of the environment}

In Tolkien, the name, which contains the thing in its splendid material existence, creates a magical secondary world. Tolkien's writing delights in the object, gives it value in itself, independently of any narrative logic: "Tree and bird, water and stone." As Tom Shippey has observed, this is particularly true of proper names, which have a unique referent..$^{31}$ Place names, which are rare in The Hobbit, are everywhere in The Lord of the Rings and in the Silmarillion, creating a strong feeling of a world, through their onomastic power. Tolkien's professional interest in etymology and the history of the names of his region (Oxfordshire) inspired him in his descriptions of landscapes in The Lord of the Rings; and the caves of Aglarond, which we shall now discuss in conclusion, are apparently based on a visit he made to Cheddar Gorge in southern Somerset. ${ }^{32}$ It is worth noting in passing how important outdoor activities are to the growth of fantasy literature, from Tolkien's Oxfordshire rambles to Will Crowther's caving expeditions (Colossal Cave Adventure, mentioned above) via the inventors of the first "book in which YOU become the hero!," Ian Livingstone and Steve Jackson, who both say that their travels in Asia were the inspiration for what each considers to be his best work. ${ }^{33}$

Some of The Lord of the Rings's most lyrical and vivid passages occur in Gimli's description of the sumptuous Caves of Aglarond, in the chapter "The Road to Isengard." It is an example of hypotyposis, in which a description makes an object present before our very eyes, but in this case not just for us, but also for the Elf Legolas, whom the dwarf addresses, and who steps in as a model reader. Gimli's description embeds the site in a cultural geography (human and dwarf), which reinforces the reader's feeling that he or she is receiving only glimpses of a far larger world which has a life of its own beyond the present story. Gimli imagines that the military campaigns will be superseded by tourism (once the War of the Ring is over, the dwarves will make pilgrimages to this spot, in order to contemplate serenely this marvel of the natural world). The beauty of the cave will then reign supreme, as an environmental spectacle and an aesthetic object independent of any utilitarian or military ends. A productive tension is at work between the role of this marvellous image in the development of the narrative (of warfare), orientating it towards a peaceful goal of tourism, and on the other hand, the image's vastness, which tends to separate it off from the whole.

The energy or energeia fuelling this hypotyposis is the aesthetic and emotional impact of the sublime natural beauty experienced by Gimli. The beginning of his tirade is full of emotion, as he tells Legolas that his heart is still bursting with the sense of beauty of the Caves of Aglarond ("my heart is still full of it"). He continues:

And, Legolas, when the torches are kindled and men walk on the sandy floors under the echoing domes, ah! then, Legolas, gems and crystals and veins of precious ore glint in the polished walls; and the light glows through folded marbles, shell-like, 
translucent as the living hands of Queen Galadriel. There are columns of white and saffron and dawn-rose, Legolas, fluted and twisted into dreamlike forms; they spring up from many-colored floors to meet the glistening pendants of the roof: wings, ropes, curtains fine as frozen clouds; spears, banners, pinnacles of suspended palaces! Still lakes mirror them: a glimmering world looks up from dark pools covered with clear glass; cities, such as the mind of Durin could scarce have imagined in its sleep, stretch on through avenues and pillared courts, on into the dark recesses where no light can come. And plink! A silver drop falls, and the round wrinkles in the glass make all the towers bend and waver like weeds and corals in a grotto of the sea. ${ }^{34}$

31 The rhythmic structure of this most musical of passages is complex, articulated around the interjection "Legolas," which makes the reader in turn listen attentively. This modulation of attention arguably leads to greater immersion in the scene. The marker of emotion "ah!" breaks the flow of the sentence, which then runs on in a list of nouns (gems and crystals and veins of precious ore). Rock becomes supple and translucent, full of life, and multi-coloured. It rises and twists, in a sentence which contains two semicolons, one colon, and an exclamation mark. The lists conjure up a fantastical world of airy forms (wings, ropes, curtains, frozen clouds), which becomes more complex and multiple, with an added world of water, and whole cityscapes (still lakes, dark pools, cities, avenues and pillared courts). This spectacular visual world endowed with agency ( $a$ world looks up) is suddenly interrupted by the onomatopoeia of "And plink!" The mimed sound brings us back into the present of contemplation, immersing us "like weeds and corals in a grotto of the sea".

We could take this analysis further, but our question is why such stylistic and rhetorical intensity is concentrated at this point. This virtuoso passage is a kind of textual jewel, a sumptuous ornament of evocative nouns. It is Gimli's gift to Legolas, and Tolkien's to his reader, after a particularly gruelling episode. This gift contributes to an aesthetic economy in which the spectacle of the environment tends to become divorced from the narrative, like an added, and excessive, ornament. Video games are criticised for similar excesses in their use of spectacular cinematic sequences, often as the gamer's reward after a difficult test..$^{35}$

The development of computing and video games therefore intensified and valorised, retrospectively, one particular type of aesthetic relation from within the literary tradition of Fantasy, namely the exploration and inhabiting of spectacular environments. Video game technologies enable players to roam inside imaginary worlds already conjured up in literature, thus enlarging our everyday lived environments, providing us with peaceful retreats untouched by obligations to act, and encouraging a contemplative stance towards the environment. Time will tell whether this type of engagement privileged by role-playing video games will, reciprocally, become more common in literary narratives (for example, the forms of dwelling found in the novel House of Leaves by Mark Z. Danielewski, 2000), and in the art world (where immersive environments have been very much in fashion since the turn of the twentyfirst century); or whether, on the contrary, literature will abandon immersion in the environment in favour of other dimensions of the aesthetic experience. 


\section{BIBLIOGRAPHY}

“A Walk Through Skyrim: The Rift," YouTube. [Online] https://www.youtube.com/watch? $\mathrm{v}=$ ONYCV35t04s [accessed 21 November 2018].

AARSETH Espen, "Allegories of Space. The Question of Spatiality in Computer Games," in Borries Friederich von, Walz Steffen P. and Böttger Matthias (dir.), Space Time Play, Basel, Birkhäuser, 2007, p. 44-47.

Aмато Étienne Armand, "L'immersion par le jeu video: origine et pertinence d'une métaphore signifiante," in Bernard Guelton (dir.), Les Figures de l'immersion, Rennes, Presses Universitaires de Rennes, 2013, p. 39-59.

CALLEJA Gordon, In Game. From Immersion to Incorporation, Cambridge, MIT Press, 2011.

CARPENTER Humphrey, The Letters of J.R.R. Tolkien, Boston, Houghton Mifflin Harcourt, 2014.

Collins Christopher, Paleopoetics. The Evolution of the Preliterate Imagination, New York, Columbia University Press, 2013.

GREEN Jonathan, You are the Hero. A History of Fighting Fantasy Gamebooks, Bucks, Snowbooks, 2014.

HAMON Philippe, Introduction à l'analyse du descriptif, Paris, Hachette, 1981.

HAYLES N. Katherine, Electronic Literature. New Horizons for the Literary, Notre Dame, University of Notre Dame Press, 2008.

HowARD Robert Ervin, “The Hyborian Age,” The Complete Chronicles of Conan [1936], Londres, Gollancz, 2006, p. 1-20

Horowitz Michael et Palmer Cynthia (dir.), Moskha. Aldous Huxley's Classic Writings on Psychedelics and the Visionary Experience [1977], Rochester, Park Street Press, 1999.

JACKSON Steve and LIVINGSTONE Ian, The Warlock of Firetop Mountain [1982], 25 $5^{\text {th }}$ anniversary edition, Cambridge, Wizard Books, 2007.

Jenkins Henry, "Game Design as Narrative Architecture," in Noah WARDRIP-FRUIN and Pat HARRIGAN (dir.), First person. New Media as Story, Performance, and Game, Cambridge, MIT Press, 2004, p. $118-130$.

JUUL Jesper, Half-Real. Videogames Between Real Rules and Fictional Worlds, Cambridge, MIT Press, 2005.

KING Brad and BoRLAND John, Dungeons and Dreamers. The Rise of Computer Game Culture from Geek to Chic, Emeryville, McGraw-Hill/Osborne, 2003.

KING Geoff and KrZYwinsKa Tanya, Tomb Raiders and Space Invaders. Videogames Forms and Contexts, London/New York, I.B. Taurus, 2006

KLEVIER Rune, "In Defense of Cutscenes," in Mayra Frans (dir.), Proceedings of Computer Games and Digital Cultures Conference, Tampere, Tampere University Press, 2002.

Leroi-Gourhan André, Le Geste et la Parole, vol. 1, Technique et langage, Paris, Albin Michel, 1964.

MACÉ Marielle, Façons de lire, manières d'être, Paris, Gallimard, 2011. 
MonTANi Pietro, Bioesthétique. Sens commun, technique et art à l'âge de la globalisation, Paris, Vrin, 2013.

MONTFORT Nick, Twisty Little Passages. An Approach to Interactive Fiction, Cambridge, MIT Press, 2005.

MunRo Alice, "What is real ?," in Tammy RoBerTs, Mical Moser, Don LePAN, Julian GAUNCE and Laura BUZZARD (dir.), The Broadview Anthology of Expository Prose. Second Edition [1982], Calgary, Broadview Press, 2011.

NEWMAN James, Playing With Videogames, London/New York, Routledge, 2008.

RYAN Marie-Laure, Avatars of Story, Minneapolis/London, University of Minnesota Press, 2006.

SHIPPEY Tom, J.R.R. Tolkien. Author of the Century, London, Harper Collins, 2000.

THÉRRIEN Carl, Illusion, idéalisation, gratification. L'immersion dans les univers de fiction à l'ère du jeu vidéo, doctoral thesis in semiology, Montréal, Université du Québec à Montréal, 2011.

ToLKIEN John Ronald Reuel, Tree and Leaf, Boston, Houghton Mifflin Company, 1965.

TolKIEN John Ronald Reuel, The Two Towers [1954], Boston, Houghton Mifflin Company, 1982.

TUAN Yu-Fi, Escapism, Baltimore, Johns Hopkins University Press, 1998.

VERCRUYSSE Thomas, "Façons de lire, manières de devenir. La lecture comme occasion d'une éthopoétique," Épistémocritique, 2015. [Online] http://epistemocritique.org/facons-de-liremanieres-de-devenir-la-lecture-comme-occasion-dune-ethopoetique/ [accessed 14 december 2015].

\section{NOTES}

1. N. Katherine Hayles, Electronic Literature. New Horizons for the Literary, Notre Dame, University of Notre Dame Press, 2008, p. 118.

2. In Dungeons and Dreamers, King and Borland address this particular historical period through the biography of Richard Garriot (the creator of the video game series Ultima). They describe how he spent time in a programming camp when he was only a teenager, in 1977 (Brad King and John Borland, Dungeons and Dreamers. The Rise of Computer Game Culture from Geek to Chic, Emeryville, McGraw-Hill/Osborne, 2003).

3. Marie-Laure Ryan, Avatars of Story, Minneapolis/London, University of Minnesota Press, 2006, p. 127.

4. James Newman, Playing With Videogames, London/New York, Routledge, 2008. 48 sq.

5. See on this subject Aldous Huxley's essay of 1977. Michael Horowitz and Cynthia Palmer (dir.), Moskha. Aldous Huxley's Classic Writings on Psychedelics and the Visionary Experience, Rochester, Park Street Press, 1999, p. 119, and the studies by the geographer Yu-Fi Tuan, Escapism, Baltimore, Johns Hopkins University Press, 1998.

6. Brad King and John Borland, Dungeons and Dreamers. The Rise of Computer Game Culture from Geek to Chic, Emeryville, McGraw-Hill/Osborne, 2003, p. 21.

7. Pietro Montani, Bioesthétique. Sens commun, technique et art à l'âge de la globalisation, Paris, Vrin, 2013, p. 106.

8. André Leroi-Gourhan, Gesture and Speech, translated by Anna Bostock Berger [Le Geste et la Parole, vol. 1, Technique et langage, Paris, Albin Michel, 1964], Cambridge, MIT Press, 1993.

9. Christopher Collins, Paleopoetics. The Evolution of the Preliterate Imagination, New York, Columbia University Press, 2013, p. 133. 
10. Christopher Collins, Paleopoetics. The Evolution of the Preliterate Imagination, New York, Columbia University Press, 2013, p. 154.

11. On this oscillation, see the study by Marielle Macé, Façons de lire, manières d'être, Paris, Gallimard, 2011, p. 53, and by Thomas Vercruysse, "Façons de lire, manières de devenir. La lecture comme occasion d'une éthopoétique," Épistémocritique, 2015. [Online] http:// epistemocritique.org/facons-de-lire-manieres-de-devenir-la-lecture-comme-occasion-duneethopoetique/ [accessed 14 December 2015].

12. Yu-Fi Tuan, Escapism, Baltimore, Johns Hopkins University Press, 1998, p. 38.

13. Robert Ervin Howard, "The Hyborian Age," The Complete Chronicles of Conan [1936], London, Gollancz, 2006, p. 1-20

14. John Ronald Reuel Tolkien, Tree and Leaf, Boston, Houghton Mifflin Company, 1965, p. 51.

15. John Ronald Reuel Tolkien, Tree and Leaf, Boston, Houghton Mifflin Company, 1965, p. 9.

16. Espen Aarseth, "Allegories of Space. The Question of Spatiality in Computer Games," in Friederich von Borries, Steffen P. Walz and Matthias Böttger (dir.), Space Time Play, Basel, Birkhäuser, 2007, p. 44.

17. Henry Jenkins, "Game Design as Narrative Architecture," in Noah Wardrip-Fruin and Pat Harrigan (dir.), First Person. New Media as Story, Performance, and Game, Cambridge, MIT Press, 2004, p. 121.

18. I thank the anonymous peer-reviewer who reminded me of the importance of these "nonspatial games."

19. Geoff King and Tanya Krzywinska, Tomb Raiders and Space Invaders. Videogames Froms and Contexts, London/New York, I.B. Taurus, 2006, p. 156.

20. See Brad King and John Borland, Dungeons and Dreamers. The Rise of Computer Game Culture from Geek to Chic, Emeryville, McGraw-Hill/Osborne, 2003, p. 31.

21. Nick Montfort, Twisty Little Passages. An Approach to Interactive Fiction, Cambridge, MIT Press, 2005, p. 4.

22. Geoff King and Tanya Krzywinska, Tomb Raiders and Space Invaders. Videogames Froms and Contexts, London/New York, I.B. Taurus, 2006, p. 156.

23. Geoff King and Tanya Krzywinska, Tomb Raiders and Space Invaders. Videogames Froms and Contexts, London/New York, I.B. Taurus, 2006, p. 91.

24. Gordon Calleja, In-Game. From Immersion to Incorporation, Cambridge, MIT Press, 2011, p. 1.

25. Alice Munro, "What is real?" ([982], in Tammy Roberts, Mical Moser, Don LePan, Julian Gaunce and Laura Buzzard (dir.). The Broadview Anthology of Expository Prose. Second Edition, Calgary, Broadview Press, 2011, p. 267.

26. Étienne Armand Amato, "L'immersion par le jeu vidéo: origine et pertinence d'une métaphore significative," in Bernard Guelton (dir.), Les Figures de l'immersion, Rennes, Presses Universitaires de Rennes, 2014, p. 54.

27. For example, “A Walk Through Skyrim: The Rift," YouTube. [Online] https:// www.youtube.com/watch?v=ONYCv35t04s [accessed 21 November 2018].

28. For a study of the strategies used in constructing imaginary worlds in the series The Elder Scrolls, of which Skyrim is the fifth chapter, see Carl Thérrien, Illusion, idéalisation, gratification. L'immersion dans les univers de fiction à l'ère du jeu vidéo, thesis presented in partial fulfilment of the requirements of a doctoral thesis in Semiology, Montréal, UQAM, 2011.

29. Jesper Juul, Half-Real. Videogames Between Real Rules and Fictional Worlds, Cambridge, MIT Press, 2005.

30. Philippe Hamon, Introduction à l'analyse du descriptif, Paris, Hachette, 1981, p. 185-186.

31. Tom Shippey, J.R.R. Tolkien. Author of the Century, Londres, Harper Collins, 2000, p. 57.

32. Humphrey Carpenter, The Letters of J.R.R. Tolkien, Boston, Houghton Mifflin Harcourt, 2014, p. 407. 
33. Steve Jackson and Ian Livingstone, The Warlock of Firetop Mountain [1982], 25 $5^{\text {th }}$ anniversary edition, Cambridge, Wizard Books, 2007, p. 220.

34. John Ronald Reuel Tolkien, The Two Towers [1954], Boston, Houghton Mifflin Company, 1982, p. 152-153.

35. For a presentation of the debate concerning cinematic scenes, see Rune Klevier, «In Defense of Cutscenes ", in Frans Mayra (dir.), Proceedings of Computer Games and Digital Culture Conference, Tampere, Tampere University Press, 2012.

\section{ABSTRACTS}

Since the 1970s, video games became very interested in the narrative. What impact does this form of art, born of a computer-marked technical environment, have on our way of apprehending the literary text, of experiencing narrative and fiction in the twenty-first century? We question these impacts by exploring the genre of fantasy, shared by role-playing video games and fiction narratives, and which defines an influence matrix organized around an aesthetic principle of exploration and the incarnation of secondary universes that makes the environmental immersion possible. We will look into how fantasy tends to free the description of the narrative requirements and to spare spaces of sovereignty for the environmental spectacle.

\section{INDEX}

Keywords: environment, fantasy, immersion, reading, video game, Tolkien

\section{AUTHORS}

\section{PIERRE-LOUIS PATOINE}

Assistant professor of American literature at Sorbonne-Nouvelle University, Pierre-Louis Patoine is the author of a book on the role of the empathic, physiological body in the experience of reading (Corps/texte, ENS Editions, 2015). He has published articles on contemporary American literature, biosemiotics and literary neuroaesthetics, is co-editor of the online journal Epistemocritique (http://epistemocritique.org) and co-director of the Science/Literature research group (hypotheses.litorg.org). 